G. Mazza, A.S.P.S. Reboleira, F. Gonçalves, L. Aquiloni, A.F. Inghilesi, D. Spigoli, F. Stoch, S. Taiti, F. Gherardi, and E. Tricarico - A new threat to groundwater ecosystems: first occurrences of the invasive crayfish Procambarus clarkii (Girard, 1852) in European caves. Journal of Cave and Karst Studies, v. 76, no. 1, p. 62-65. DOI: 10.4311/2013LSC0115

\title{
A NEW THREAT TO GROUNDWATER ECOSYSTEMS: FIRST OCCURRENCES OF THE INVASIVE CRAYFISH PROCAMBARUS CLARKII (GIRARD, 1852) IN EUROPEAN CAVES
}

\author{
Giuseppe Mazza ${ }^{*}$, Ana Sofia P.S. Reboleira ${ }^{2,3}$, Fernando Gonçalves², Laura Aquiloni' ${ }^{1}$, \\ Alberto F. Inghilesi ${ }^{1}$, Daniele Spigoli ${ }^{1}$, Fabio $\mathrm{S}_{\text {toch }}^{4}$, Stefano Taiti ${ }^{5}$, \\ Francesca Gherardi', ANd Elena Tricarico ${ }^{1}$
}

\begin{abstract}
The American red swamp crayfish, Procambarus clarkii, is today the alien species most widespread in European water bodies. This invasive crayfish was found for the first time in some caves of Europe, specifically in Portugal and Italy. The presence of $P$. clarkii in caves is noteworthy, representing a new threat for the groundwater ecosystems due to the possible negative impacts on the native communities.
\end{abstract}

\section{INTRODUCTION}

The subterranean environment hosts unique biological communities of remarkable diversity that, however, are still understudied in large parts of Europe (Gibert and Culver, 2009). Groundwater biodiversity has attracted much attention in recent years for two important aspects: the distinctiveness of its fauna, whose composition is highly different from that of surface freshwater fauna, and its narrow endemism (Deharveng et al., 2009). This particular habitat is vulnerable to local extinctions caused by anthropogenic impacts such as groundwater pollution, water abstraction, and habitat deterioration (Danielopol et al., 2003). Biological invasions, one of the most significant components of human-induced environmental change, could also imperil this environment (Lodge et al., 2000; Sala et al., 2000). Specifically, invasive species exert particularly heavy impacts in inland waters (Sala et al., 2000), where they threaten biodiversity, leading to extinction of indigenous species (Lodge, 2001; Gherardi, 2007) and altering the structure and function of ecosystems (Mack and D'Antonio, 1998; Strayer, 1999). Invasive species colonizing the subterranean environment by way of rivers have already been reported in Europe, e.g., the Asiatic clam Corbicula fulminea (Müller, 1774) in France (Callot-Girardi et al., 2012) and the New Zealand mudsnail Potamopyrgus antipodarum (Gray, 1843) in Italy (Bodon et al., 2009).

One of the most successful and best known invasive species of aquatic ecosystems in Europe is the North American red swamp crayfish Procambarus clarkii (Girard, 1852), now widely distributed in the world due to its biological features such as plastic life cycle, high fecundity, ability to rapidly disperse in the habitat, and tolerance to environmental extremes (Gherardi, 2006). This successful invader, that can cause a large variety of impacts (see Savini et al., 2010), was first introduced in Portugal in the 1970s and then in Italy in the 1980s, and it has now colonized most of the surface freshwater systems of both countries (Correia, 2003; Aquiloni et al., 2010). Here we report the first occurrences of this invasive crayfish in some cave waters of Portugal and Italy and briefly discuss the implications of this discovery for this unique and complex aquatic environment.

\section{Materials And Methods}

Procambarus clarkii was collected in July 2007 in the Sicó massif (Anços spring: 3958'42.41”N 8³4'22.67”W) and observed since August 2007 in the Estremenho massif (Olhos de Água do Alviela: $39^{\circ} 26^{\prime} 44.25^{\prime \prime} \mathrm{N} 8^{\circ} 42^{\prime} 43.63^{\prime \prime} \mathrm{W}$ ), both caves being located in central Portugal. It was also collected in September 2011, October 2012, and February 2013 in pools inside of the adjoining Grotta del Leone, Grotta del Lago, Buca della croce di Agnano n. 2, Buca dell'acqua presso la Buca di Agnano, and Buca dei Ladri in the Monti Pisani area: $43^{\circ} 44^{\prime} 17.7^{\prime \prime} \mathrm{N} 10^{\circ} 28^{\prime} 24.8^{\prime \prime} \mathrm{E}$, municipality of San Giuliano Terme, Pisa Province, Tuscany Region, Central Italy (Fig. 1). The Portuguese caves are located in two karst massifs and are up to 110-m deep and 700-m long. In Italy, Monte Pisano includes a group of hills, rich in karst caves and quarries, extending from northwest to southeast between the Lucca and Pisa plains in northwestern Tuscany.

In Portugal, specimens were collected by active search with dip-nets, while in Italy also by baited traps left

\footnotetext{
*Corresponding author, giuseppe.mazza@unifi.it

${ }^{1}$ Dipartimento di Biologia, Università degli Studi di Firenze, Via Romana 17, 50125 Firenze, Italy

${ }^{2}$ Department of Biology and CESAM, University of Aveiro, Campus Universitário de Santiago, 3810-193 Aveiro, Portugal

${ }^{3}$ Departamento de Biología Animal, Universidad de La Laguna, 38206 La Laguna, Spain

${ }^{4}$ Dipartimento di Medicina clinica, Sanità pubblica, Scienze della vita e dell'ambiente, Università dell'Aquila, Via Vetoio, Coppito, 67100 L'Aquila, Italy

${ }^{5}$ Istituto per lo Studio degli Ecosistemi, Consiglio Nazionale delle Ricerche, Via Madonna del Piano 10, 50019 Sesto Fiorentino (Firenze), Italy
} 


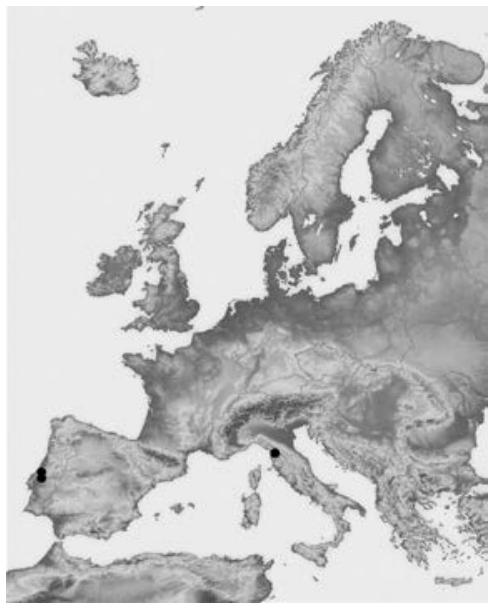

Figure 1. Approximate locations of sampled caves with Procambarus clarkii in Europe.

overnight. In Italy, sampling also was conducted in the nearby epigean channel by both methods. For each crayfish, sex was determined and the length of the cephalothorax (CL), from the tip of the rostrum to the posterior edge of the carapace, was measured using a caliper with $0.1 \mathrm{~mm}$ precision. The number of individuals partially or totally depigmented was recorded.

The associated aquatic fauna was also sampled and recorded using dip-nets and small baited traps. Portuguese material is deposited at the Museu Nacional de História Natural, Lisbon, and the Italian samples at the Department of Biology, Florence.

During the surveys, the following water parameters were recorded with a multiparameter sonde: temperature, $\mathrm{pH}$, dissolved oxygen, conductivity, and $\mathrm{NH}_{4}^{+}$. Frequency data were analyzed by $\mathrm{G}$ test with Williams correction (statistic G). Differences in CL between the sexes were compared by t-test for independent samples (statistic $\mathrm{t}$ ).

\section{RESUlts}

Since 2007, six specimens of Procambarus clarkii have been observed in the groundwater of the Anços and Alviela springs in Portugal. Both caves are active resurgences, although the Rio Anços may dry up in the peak of summer. The individuals found inside the caves are totally depigmented, and one male was collected at 40-m depth in the Anços spring $(\mathrm{CL}=33.1 \mathrm{~mm}$; Fig. 2). Pigmented adults of the species are abundant (two individuals per meter) in the corresponding surface streams.

In Italy, a total of fifteen specimens of $P$. clarkii were collected from Grotta del Leone (one female: CL = $34 \mathrm{~mm}$ ), Grotta del Lago (two males: $\mathrm{CL}=33.9 \pm$ $0.05 \mathrm{~mm}$ and one female: $\mathrm{CL}=23.1 \mathrm{~mm}$ ), Buca della croce di Agnano n. 2 (one male: $\mathrm{CL}=26.4 \mathrm{~mm}$ and three females: $C L=24 \pm 5.5 \mathrm{~mm}$ ), Buca dell'acqua presso la Buca di Agnano (five males: $\mathrm{CL}=23.5 \pm 2.1 \mathrm{~mm}$ and one

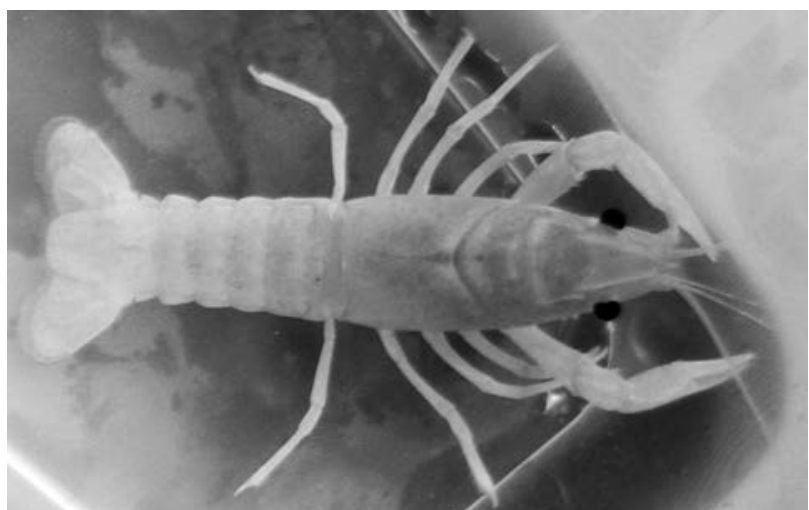

Figure 2. Depigmented specimen of Procambarus clarkii found in Anços spring, Portugal.

female: $\mathrm{CL}=33.7 \mathrm{~mm}$ ) and Buca dei Ladri (one male: $\mathrm{CL}$ $=38.8 \mathrm{~mm}$ ). About $53 \%$ of the crayfish had pereopods and cephalothorax bluish-whitish in color. The pools inside the caves were also inhabited by several species of Crustacea, the most abundant invertebrates in groundwater (Botoşăneanu, 1986), such as many species of stygobiotic copepods of the genera Acanthocyclops and Diacyclops and several specimens of amphipods belonging to Salentinella angelieri pisana Ruffo, 1953 (Salentinellidae, endemic to Monti Pisani karstic massif), Niphargus sp. group speziae Schellenberg, 1936, and Niphargus sp. prope stefanellii Ruffo and Vigna-Taglianti, 1968. Both Niphargidae are probably species new to science, according to F. Stoch and J.F. Flot. In Grotta del Lago, we also found three adult specimens of the European eel Anguilla anguilla (Linnaeus, 1758).

In the nearby epigean channel we collected fifty-six individuals of $P$. clarkii with a balanced sex-ratio (males $=$ 32; females $=24 ; \mathrm{G}=1.14, \mathrm{df}=1, p>0.1$ ) and a similar mean size $(\mathrm{CL}$ males $=35.7 \pm 2.2 \mathrm{~mm}$; $\mathrm{CL}$ females $=$ $39.1 \pm 2.4 \mathrm{~mm} ; \mathrm{t}=1.03, \mathrm{df}=54, p=0.31)$. All the crayfish were pigmented. The invasive mosquitofish Gambusia holbrooki Girard, 1859, the crucian carp Carassius carassius (Linnaeus, 1758) and the black bullhead Ameiurus melas (Rafinesque, 1820) were also abundant in this channel. Concerning the water parameters, the Portuguese and Italian caves had similar temperatures (nearly constant during the year), $\mathrm{pH}$, conductivity, and $\mathrm{NH}_{4}^{+}$. Only the epigean channel showed a wide range of temperatures (Table 1).

\section{DisCUSSION}

To the best of our knowledge, these are the first documented occurrences of the invasive crayfish Procambarus clarkii in European caves. In Europe, crayfish occasionally found in subterranean habitats have been almost unknown or rarely reported, and only identified native species, such as Austropotamobius torrentium (Schrank, 1803) (Koutrakis et al., 2005). The only large

Journal of Cave and Karst Studies, April 2014•63 


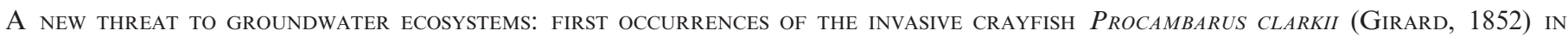
EUROPEAN CAVES

Table 1. Waterparameter ranges recorded in the Portuguese and Italian study areas.

\begin{tabular}{lccccc}
\hline Sites & $\begin{array}{c}\text { Water } \\
\text { Temperature, }{ }^{\circ} \mathrm{C}\end{array}$ & $\mathrm{pH}$ & Oxygen, $\mathrm{mg} \mathrm{L}^{-1}$ & $\begin{array}{c}\text { Conductivity, } \\
\mu \mathrm{S} \mathrm{cm}^{-1}\end{array}$ & $\mathrm{NH}_{4}^{+}, \mathrm{mg} \mathrm{L}^{-1}$ \\
\hline Anços & $15.8-16.4$ & 7 & $8.5-9.5$ & $497-540$ & 0 \\
Alviela & $15.6-17.5$ & 7 & 7.6 & $443-508$ & 0 \\
Epigean channel & $11-31$ & 6 & 5.4 & $482-500$ & 0.4 \\
Grotta del Leone & $16-17$ & 6 & 4.3 & $524-540$ & 0 \\
Grotta del Lago & $14.5-17.7$ & 6 & 4.3 & $560-585$ & 0 \\
Buca della croce di Agnano n. 2 & $12-19$ & 7 & $1.4-2.5$ & $695-730$ & 0.6 \\
Buca dell'acqua presso la Buca & $15-23$ & 6.5 & 3.9 & $503-515$ & 0 \\
$\quad$ di Agnano & & & 5 & $498-516$ & 0 \\
Buca dei Ladri & $14.5-18$ & 6.5 & 5 & 4.6 & 0 \\
\hline
\end{tabular}

stygobiotic decapod in Europe is represented by the blind prawn genus Typhlocaris Calman, 1909, present in Italy (Apulia) with the species T. salentina Caroli, 1923. The family Cambaridae is represented in the troglobiotic American fauna with four genera, three of which have epigean members as well (Procambarus Ortmann, 1905, Orconectes Cope, 1872, and Cambarus Erichson, 1846: Hobbs et al. 1977; Hobbs, 1988). For example, in Florida, thirteen of the fifty-two known species and subspecies are troglobites, while in southern Indiana six species or subspecies inhabit the subterranean caves in the karst region (Hobbs, 1988; Hogger, 1988). There are also cases among the Cambaridae of stigoxenic (largely confined to surface water) and stygophilic (able to spend part of their life in ground waters but without or with limited specialization to subterranean life) species. Specifically, $P$. clarkii has been found in caves of Texas (Hobbs et al., 1977), probably due to the displacement of populations living in epigean environments. In Portugal, the individuals found in ground waters were totally depigmented, while in Italy pigmentation of cave-dwelling individuals of $P$. clark $i$ occurs. The presence of mostly pigmented crayfish inside the Italian caves could indicate a more recent invasion; an external source of carotenoids, which can occur in caves providing a source of food for crayfish as mentioned in Hogger (1988) and in Koutrakis et al. (2005), even if it is probably not abundant, as evidenced by the presence of bluish individuals; or movement from the epigean channel to the caves and vice versa, due to the locomotory activity of crayfish. The individuals found in Monti Pisani area can be undoubtedly classified as stygoxenic, while specimens from Portugal show a certain degree of stygobization. In both areas, the caves showed similar water conditions favorable for the species; only the oxygen differed substantially among sites, but $P$. clarkii can tolerate a wide range of oxygen content, being capable of air breathing (Huner, 2002).

The presence of Procambarus clarkii in caves is noteworthy, due to the possible negative impacts on native communities. This species is recognized as one of the most invasive crayfish in Europe (Tricarico et al., 2010) and, thanks to its plasticity, it can prey on many endemic cave species, since it feeds on diverse items in proportion to their availability. The European groundwater fauna comprises more than 1,800 stygobitic species (Stoch and Galassi, 2010), most of them endemic to restricted areas or single karstic massifs in southern countries. At least sixty-seven groundwater-dwelling species are endemic to Portugal (Reboleira et al., 2011, 2013), and P. clarkii could be an important threat to some of these species, such as asellid isopods like Proasellus lusitanicus (Frade, 1938), as well as amphipods belonging to the genus Pseudoniphargus Chevreux, 1901. Groundwater biodiversity is even greater in Italy, with more than 320 stygobiotic species reported in recent catalogues (Ruffo and Stoch, 2006, and Fauna Europaea Web Service, 2013), around 300 of them being endemic. In the karstic area where it was found, P. clarkii can feed on the amphipods of the genus Niphargus (two species yet to be described) and Salentinella angelieri pisana, all endemics to the restricted area of Monti Pisani. However, in Italy, the eels in the pools could control the population of $P$. clarkii; indeed Anguilla anguilla actively preys on crayfish juveniles (Aquiloni et al., 2010).

Further studies are necessary to investigate more deeply the status of this species in caves and to assess how the species arrived and the possible impacts on this particular habitat.

\section{ACKNOWLEDGEMENTS}

Authors are grateful to Gruppo Speleologico CAI, Pisa, and in particular to P. Mannucci, G. Stasolla, and D. Abiuso (University of Florence) for field assistance. We express our gratitude to A. Correia (Museu Nacional de História Natural) for species identifications and to SAGA and NEUA cave divers J. Neves, L. Neves, J. Morrison, M. Lança, R. Pinheiro, and M. Lopes and to J. Meynié, for the first observations and collections of $P$. clarkii in caves of Portugal and also to DIR-SPE for support on cave diving.

\section{REFERENCES}

Aquiloni, L., Brusconi, S., Cecchinelli, E., Tricarico, E., Mazza, G., Paglianti, A., and Gherardi, F., 2010, Biological control of invasive populations of crayfish: the European eel (Anguilla anguilla) as a 
predator of Procambarus clarkii: Biological Invasions, v. 12, p. 3817-3824. doi:10.1007/s10530-010-9774-z.

Bodon, M., Cianfanelli, S., and Montanari, A., 2009, Mollusks of the Frasassi karstic complex and adjacent sulfidic spring: Abstract with Program, The Frasassi Stygobionts and their Sulfidic Environment, Genga, September 10-13, 2009, p. 9-11.

Botoşăneanu, L., ed., 1986, Stygofauna Mundi. A Faunistic, Distributional and Ecological Synthesis of the World Fauna Inhabiting Subterranean Waters (Including the Marine Interstitial), Leiden, E. J. Brill/Dr. W. Backhuys, 740 p.

Callot-Girardi, H., Wienin, M., and Galéra, J.-L., 2012, Présence de Corbicula fluminea (Müller, 1774), en milieu cavernicole, dans la Cèze souterraine à Méjannes-le-Clap, Gard, France. Le perte de la Baume Salène, un site écologique confiné remarquablement riche: Folia Conchyliologica, no. 18, p. 3-14.

Correia, A.M., 2003, Food choice by the introduced crayfish Procambarus clarkii: Annales Zoologici Fennici, v. 40, p. 517-528.

Danielopol, D.L., Griebler, C., Gunatilaka, A., and Notenboom, J., 2003, Present state and future prospects for groundwater ecosystems: Enviromental Conservation, v. 30, p. 104-130. doi:10.1017/ S0376892903000109.

Deharveng, L., Stoch, F., Gibert, J., Bedos, A., Galassi, D., Zagmajster, M., Brancelj, A., Camacho, A., Fiers, F., Martin, P., Giani, N., Magniez, G., and Marmonier, P., 2009, Groundwater biodiversity in Europe: Freshwater Biology, v. 54, p. 709-726. doi:10.1111/j.13652427.2008.01972.x.

Fauna Europaea Web Service, 2013, Fauna Europaea Version 2.6. http:// www.faunaeur.org, (accessed April 15, 2013).

Gherardi, F., 2006, Crayfish invading Europe: the case study of Procambarus clarkii: Marine and Freshwater Behaviour and Physiology, v. 39, no. 3, p. 175-191. doi:10.1080/10236240600869702.

Gherardi, F., 2007, The impact of freshwater NIS: what are we missing?, in Gherardi, F., ed., Biological Invaders in Inland Waters: Profiles, Distribution, and Threats, Dordrecht, Springer, Invading NatureSpringer Series in Invasion Ecology, vol 2, p. 437-462.

Gibert, J., and Culver, D.C., 2009, Assessing and conserving groundwater biodiversity: an introduction: Freshwater Biology, v. 54, p. 639-648. doi:10.1111/j.1365-2427.2009.02202.x.

Hobbs, H.H. Jr., Hobbs, III., H.H., and Margaret, A.D., 1977, A Review of the Troglobitic Decapod Crustaceans of the Americas, Washington DC, Smithsonian Contributions to Zoology 244, 187 p.

Hobbs, H.H. Jr., 1988, Crayfish distribution, adaptive radiation and evolution, in: Holdich, D.M., and Lowery, R.S., eds., Freshwater Crayfish: Biology, Management and Exploitation, London, Croom Helm, 52-82 + 426-479.

Hogger, J.B., 1988, Ecology, population biology and behavior, in Holdich, D.M., and Lowery, R.S., eds., Freshwater Crayfish: Biology, Management and Exploitation, London, Croom Helm, 114-144 + 426-479.

Huner, J.V., 2002, Procambarus, in Holdich, D.M., ed., Biology of Freshwater Crayfish, Oxford, Blackwell, p. 541-584.
Koutrakis, E.T., Machino, Y., Kallianiotis, A., and Holdich, D.M., 2005, Austropotamobius torrentium (Schrank, 1803) in the Aggitis Cave (Northern Greece). Is it a cave-dwelling species?: Bulletin Français de la Pêche et de la Pisciculture, v. 376-377, p. 529-538. doi:10.1051/ kmae:2005012.

Lodge, D.M., Taylor, C.A., Holdich, D.M., and Skurdal, J., 2000, Nonindigenous crayfishes threaten North American freshwater biodiversity: Lessons from Europe: Fisheries, v. 25, p. 7-20. doi:10.1577/1548-8446(2000)025<0007:NCTNAF > 2.0.CO;2.

Lodge, D.M., 2001, Lakes, in Chapin, III., F.S., Sala, O.E., and HuberSannwald, E., eds., Global Biodiversity in a Changing Environment: Scenarios for the 21st Century, New York, Springer-Verlag, Ecological Studies series 152, p. 277-313.

Mack, M.C., and D'Antonio, C.M., 1998, Impacts of biological invasions on disturbance regimes: Trends in Ecology \& Evolution, v. 13, p. 195-198. doi:10.1016/S0169-5347(97)01286-X.

Reboleira, A.S.P.S., Borges, P.A.V., Gonçalves, F., Serrano, A.R.M., and Oromí, P., 2011, The subterranean fauna of a biodiversity hotspot region - Portugal: an overview and its conservation: International Journal of Speleology, v. 40, no. 1, p. 23-37.

Reboleira, A.S.P.S., Gonçalves, F., and Oromí, P., 2013, Literature survey, bibliographic analysis and a taxonomic catalogue of subterranean fauna from Portugal: Subterranean Biology, no. 10, p. 51-60. doi:10.3897/subtbiol.10.4025.

Ruffo, S., and Stoch, F., eds., 2006, Checklist and Distribution of the Italian Fauna. 10,000 Terrestrial and Inland Waters Species: Memorie del Museo Civico di Storia Naturale di Verona, Sezione Scienze della Vita, 2 serie, no. 17, $307+$ CD-ROM.

Sala, O.E., Chapin, III., F.S., Armesto, J.J., Berlow, E., Bloomfield, J., Drizo, R., Huber-Sanwald, E., Huenneke, L.F., Jackson, R.B., Kinzig, A., Leemans, R., Lodge, D.M., Mooney, H.A., Oesterheld, M., Poff, N.L., Sykes, M.T., Walker, B.H., Walker, M., and Wall, D., 2000, Global biodiversity scenarios for the year 2100: Science, v. 287, p. 1770-1774. doi:10.1126/science.287.5459.1770.

Savini, D., Occhipinti-Ambrogi, A., Marchini, A., Tricarico, E., Gherardi, F., Olenin, S., and Gollasch, S., 2010, The top 27 animal alien species introduced into Europe for aquaculture and related activities: Journal of Applied Ichthyology, v. 26, supplement s2, p. 1-7. doi:10.1111/ j.1439-0426.2010.01503.x.

Stoch, F., and Galassi, D.M.P., 2010, Stygobiotic crustacean species richness: a question of numbers, a matter of scale: Hydrobiologia, v. 653 , p. $217-234$. doi:10.1007/s10750-010-0356-y.

Strayer, D.L., 1999, Effects of alien species on freshwater mollusks in North America: Journal of the North American Benthological Society, v. 18 , no. 1, p. 74-98.

Tricarico, E., Vilizzi, L., Gherardi, F., and Copp, G.H., 2010, Calibration of FI-ISK, an invasiveness screening tool for non-native freshwater invertebrates: Risk Analysis, v. 30, p. 285-292. doi:10.1111/j.15396924.2009.01255.x. 